\title{
The Potentials of Goodness and Badness in Humans on the Qur'an and Hadith
}

\author{
Nuraini $^{1}$, Eduwar ${ }^{2}$ \\ ${ }^{1}$ Faculty of Ushuluddin and Philosophy, UIN Ar-Raniry, Kopelma Darussalam Kota Banda Aceh, Indonesia \\ ${ }^{2}$ Faculty of Ushuluddin and Philosophy, UIN Ar-Raniry, Kopelma Darussalam Kota Banda Aceh, Indonesia \\ nuraini.husein@ar-raniry.ac.id
}

\begin{abstract}
Goodness and badness are two terms that are widely used to determine an action done by humans. All forms of human action refer to them views on goodness and badness. The value of goodness and badness will always be a source of reference in carrying out various actions in their life. Goodness and badness values are not only in philosophical studies, but also become the focus of discussion on various religious sources, including the Qur'an and Hadith. Specifically this research is directed to find out the potential in humans, in this case it is closely related to the potential goodness and badness in humans which are explained in the Qur'an and Hadith. In the QS. al-Shams: 8 stated that there is a balance of the potential of goodness and badness in humans, but in the hadith of Imam Bukhari No. 1385 stated that the potential of goodness is the most prominent in humans since being born in a state of nature. Based on these differences, the problem arises in this research that are how the views of the interpreters in interpreting verses and hadiths about the potential of goodness and badness in humans, and how to make the potential of goodness for more involved than bad. This study aims to determine the opinion of the intrepreters and find out the reasons of each intrepreter in talking about the potential of goodness and badness in humans. The results showed that the potential of goodness is the most prominent in humans, also obtained a sign that in essence the positive potential of humans is stronger than the negative potential, it's just that the attraction of badness is stronger than the attraction of goodness, therefore humans are required to maintain the purity of the soul (nafs). So that the potential of goodness is more prominent than the badness, humans should guide this potential with some instructions that have been conveyed by Allah in the Qur'an, and so have been conveyed by the Prophet in the hadith, namely by keeping the heart to remain in nature.
\end{abstract}

\section{Keywords}

goodness potential; badness potential; soul; impulse of lust; impulse

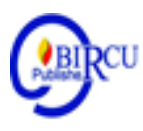

\section{Introduction}

Al-Quran contains matters relating to faith, sciences, regulations that regulate the behavior and procedures for human life. Al-Quran is also an inspiration for morals and life. Three-quarters of the contents of the Qur'an in general contain information and explanations about faith, good deeds and bad deeds, rewards for those who believe and do good deeds, threats for those who do not believe in the truth and who do bad deeds, history from previous and exemplary peoples and ibrah which can be taken from their experiences. 
The Qur'an often reveals the nature of humans, that humans are one of Allah's creations which is very interesting and in the best form. Allah SWT create humans with perfect shapes, consisting of spirits and body. Every human being created has structural characteristics (body, shape, size and dominating elements) and functional characteristics (breathing, moving and others) to maintain their life. This is in accordance with the characteristics of people who try and have the potential to do any work, including doing good and bad deeds. Good and bad deeds in humans all lead to the heart.

Islam does not allow its adherents to be preyed upon by the disease of the heart and soul, because the feelings of the heart are the way to faith and salvation. Islam requires that their people continue to purify their souls so that they gain the benefits of living in this world and the hereafter. As the word of Allah Almighty in QS. al-Shams verses 7-10 which are the subject of this study:

It means "And [by] the soul and $\mathrm{He}$ who proportioned it. And inspired it [with discernment of] its wickedness and its righteousness, He has succeeded who purifies it, And he has failed who instills it [with corruption]."

The above verse gives a description of the human soul, which is sometimes bad and sometimes good. From this verse, it can be seen that there is a description of the balance that Allah inspired in each human being, that is, between good and bad. It is humans who determine the path of their lives. Someone who chooses the path of goodness then the fortune of the afterlife will be obtained for him. Someone who chose the path of badness then the loss of the afterlife will be obtained for him as well.

The balance between good and bad in the above verse, contrasts with a hadith of the Prophet narrated from Abu Hurairah Ra:

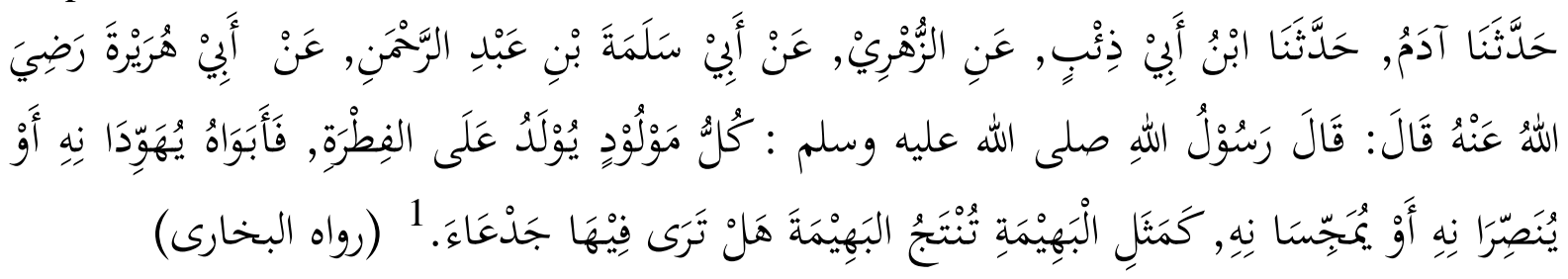

Has conveyed to us Adam, has conveyed to us Ibn Abi Zi'bin, from al-Zuhri, from Abi Salamah bin Abd Rahman, from Abu Hurairah Ra. Said: that the Messenger of Allah. said: "Every child is born in nature (pure saint), then his parents cause him (child) to become Jewish, to become Christian, or to become a Magi, like a perfectly born cattle, do you see his ear being cut off." (Narrated by Bukhari no.1385).

In this hadith it is illustrated that no human being was born into this world except in a state of mind that is fitrah (pure clean). In human beings, the most prominent potential is the good side. While badness will affect it if the environment is not good. In QS. al-Shams verses 7-10 mentioned that there is a balance between good and bad in humans. But in the hadith, the Prophet states that all humans are born in a state of nature, then there is the most prominent side in humans, namely the goodness side. While the badness arises due to environmental influences.

To find a meeting point between the two, the author will further deepen the discussion related to the verses of the Qur'an and the hadith of the Prophet by analyzing the opinions of

\footnotetext{
${ }^{1}$ Muhammad bin Ismail Abu Abdullah al-Bukhari Al-Ja'fi, al-Jami' al-Musnad al-Sahih al-Mukhtasar Min Umuri Rasulillahi Shallallahu 'Alaihi Wasallam wa Ayyamihi: Shahih al-Bukhari, Juz 2, (Beirut: Maktabah, t.th.), hal. 100.
} 
the scholars along with substantial messages that are relevant to the discussion so that they can present in detail how the potential of goodness and badness in humans.

\section{Review of Literature}

\section{Potential of Goodness and Badness in the Qur'an and Hadith}

\subsection{Potential of Goodness and Badness Definition}

Etymologically the word potential means skills, strength, ability or power. In terminology, potential is an ability that has the possibility to be developed. Potential is an ability, a power that has not yet been realized or that has been realized that is owned by someone but has not been fully seen or used optimally. According to Firus (2018) there is a personal developmental value that can be gained from developing the ability to use body language, as well as in developing other personal abilities. But this value will be greater if it can bring higher communication effectiveness seen from contributions to personal development and exploitation of human potential.

Goodness and badness are two terms that are widely used to determine an action done by humans. All forms of human action refer to their views on good and bad. The value of goodness and badness will always be a source of reference in carrying out various actions in their life. Good and bad values are not only in philosophical studies, but also become the focus of discussion on various religious sources, including the Qur'an and Hadith.

\subsection{Inventory and Classification Based on the Verses of the Qur'an}

Based on a study in the book of Konkordansi Quran by Ali Audah and also the book of Klasifikasi Kandungan al-Quran by Choiruddin Hadhiri SP., An inventory of verses about the potential for goodness and badness is as follows:

1). Surah al-Baqarah verse 272

2). Surah al-An'am verse 88

3). Surah al-A'raf verses 16-17

4). Surah Yunus verse 107

5). Surah Yusuf verse 53

6). Surah al-Anbiya 'verse 35

7). Surah al-Qashash verse 56

8). Surah al-Rum verse 30

9). Surah al-Shaffat verse 96

10). Surah al-Insan verse 3

11). Surah al-Balad verse 10

12). Surah al-Shams verses 7-10

Based on these searches, the following is an inventory of verses about the potential goodness and badness in the Qur'an which are classified into:

1) Allah's inspiration and guidance on goodness and badness in humans (Surah al-Shams: 710; Surah al-Balad: 10; Surah al-Insan: 3)

2) Test from Allah through the goodness and badness that is brought to humans (Surah alAnbiya ': 35)

3) Impulse to bad desires in humans (Surah Yusuf: 53)

4) The whisper of Satan who makes people commit bad (Surah al-A'raf: 16-17)

5) Human nature in goodness (QS. Al-Rum: 30)

6) Allah's prorogative right to show the way to goodness and badness (Surah Yunus: 107; Surah al-Qashash: 56; Surah al-Baqarah: 272; Surah al-An'am: 88) Allah creates human actions (Surat al-Shaffat: 96) 


\subsection{Inventory and Classification Based on the Hadiths of the Prophet Muhammad}

SAW:

Based on the results of searches of various books of hadith, then the hadith about the potential of goodness and badness in humans can be described as follows:

1). Bukhari History Hadith No. 3208 and Muslim No. 2036

2). Al-Tirmidhi's Hadith No. 2988

3). Bukhari History Hadith No. 1385

4). History of Abu Dawud No. 4833

5). Bukhari History Hadith No. 1362 and Muslim No. 2647

Based on these searches, the following is an inventory of traditions about the potential of goodness and badness in various books of hadith which are classified as:

1) The provision of Allah from before birth to goodness and badness in humans (Hadith narrated by Bukhari no. 3208 and Muslim no. 2036)

2) The influence of the whisper of angels and demons in the hearts of humans towards goodness and badness in humans (Hadith narrated by al-Tirmidzi no. 2988)

3) Potential of goodness and badness in humans since birth (Bukhari's historical hadith no. 1385) Environmental influences on goodness and badness in humans (Bukhari's historical hadith no. 1362 and Muslim no. 2647, Abu Dawud's hadith no. 4833)

\subsection{The Forms of deeds in the Qur'an and Hadith}

As for what the Qur'an has a lot to say about humans is their characteristics and potential. In this case, a number of verses are found which praise and glorify humans, such as: statements about the creation of humans in the best form and condition. The Word of Allah Most High, means:

"Indeed, we have created humans in the best form" (QS. Al-Tin: 4).

There is also an affirmation of the glory of this creature compared to other creatures of Allah. The word of Allah Almighty, means: "And verily We glorified the children of Adam, We transported them on land and in the sea, We gave them the fortune of the good and We exaggerate them with a perfect advantage over most of the creatures that We have created "(Surat al-Isra ': 70).

Where when the human soul is the source of happiness and misery, the Qur'an pays great attention to rectifying it with noble character and good qualities. That was mentioned globally in Surah al-Shams verses 7-10 above.

Inspiring means giving potential so that humans through the nafs can grasp the meaning of goodness and badness, and can encourage it to do good and bad. Allah SWT swear by the perfection and readiness of the human soul to accept wickedness and piety.

\section{a. Purification of the Soul}

The foundations that sustain the upright and simple-hearted human soul in the Qur'an and the hadith are numerous, including what Luqman al-Hakim said when advising his son, as mentioned in the QS. Luqman verse 13, means: And [mention, O Muhammad], when Luqman said to his son while he was instructing him, "O my son, do not associate [anything] with Allah. Indeed, association [with him] is great injustice."

The wisdom according to Wahbah al-Zuhaili is an effort to achieve the perfection of the human soul by taking theoretical sciences and achieving the perfect ability to do good deeds according to ability. That is, the human spirit always requires effort to achieve perfection, improvement and purification to the degree of wisdom. For this reason, wisdom is the basis and foundation of the human soul.

Another purification of the soul is to excite Allah and not associate partners with Him. This is the most essential basis on which to base the others. For this reason, Luqman alHakim advised his son with this advice. 
After Luqman al-Hakim forbade his son from committing shirk and fostered fear by growing awareness and conviction of the knowledge and power of Allah, Luqman al-Hakim ordered his son to work on pious deeds which were the demands of monotheism, namely prayer. Namely worship only to Allah SWT solely sincere and pure solely for Him.

Performing good prayers, mentioning the names of Allah (dhikr), reading and appreciating the Qur'an, and trying to keep away from cruel and destructive sayings and deeds, are important efforts to revive and purify the heart. Because trying to fulfill the call of Allah basically trying to build sensitivity and strength of heart. The Word of Allah in QS. alAnfal verse 24, means: "O you who have believed, respond to Allah and to the Messenger when he calls you to that which gives your life. And know that Allah intervenes between a man and his heart and that to Him you will be gathered".

\section{b. Littering the Soul}

Disobedience is the biggest cause that will make the heart tarnished, so that the nature of clarity becomes turbid. When the soul is turbid, then it will encourage its owner to commit various bad behavior and actions. Man's obligation is to keep his soul clear so that it does not become turbid because of disobedience and violation of the signs of life that have been established by Allah. When the soul is well cared for and guarded and not tainted by disobedience, it will grow in the human soul's noble behavior and morals.

A person's soul is rooted in the heart. If the heart is dirty, then the person's behavior is like dark smoke, so that his mind will always incline to badness. Clean souls and pure hearts, which are very necessary to give birth to good deeds. Do not let the soul be left unclean by bad qualities or defiled by sin and stain, because that is a barrier to good deeds.

In a hadith the history of Imam Bukhari is mentioned, meaning:

Has conveyed to us Abu Nu'aim, delivered Zakaria from 'Amir, he said: I heard Nu'man bin Basyir, he said: I heard the Messenger of Allah. said: "The halal is clear and the haram is clear. Between the two is doubtfulness (vague) that is not known by many people. So who is away from doubtful that he has saved his religion and honor. And whoever is involved in doubtfulness, will fall into a prohibited case. As a shepherd who is pasturing animals around the forbidden fields, he will gradually enter them. Know that in the body there is a lump of flesh, if he is good then the whole body is good and if he is bad, then the whole body is bad. Know that he is the heart ". (HR. Bukhari No. 52)

Based on this hadith, it is clear that one's thoughts and words and actions are a reflection and manifestation of the heart. Good manners, positive thoughts and right actions will actually only be born from a clean and healthy heart. Conversely, dirty speech, thoughts that are always negative, and actions that tend to be wrong and always blame other people or parties, will only be born from a dirty, diseased, and even dead heart. Thus, living and sharpening the sensitivity of the heart, is a necessity for everyone who wants to survive and prosper, in this world and the hereafter.

\section{Discussion}

3.1 Analysis of Interpretation of Mufasir (Interpreter) and the Explanation of the Hadith on the Potential of Goodness and Badness in Humans

\section{a. Fitrah al-Islam}

In terms of language, the word fitrah is taken from the root word al-fathr which means hemisphere, and from this meaning other meanings are born among others that contradict or occur.

Basically, according to the nature and form of the incident, humans have the right stock and ugliness, as well as instructions and error. It is able to distinguish between the goodness 
and the badness. This ability already exists in humans. Through guidance and various other factors, the provision is raised and shaped. It is a fitri creation, a tabi'i creation and an inspired mystery. Also given the words of the Prophet in a hadith narrated by Imam Bukhari, which means:

It has been conveyed to us Adam, it has been conveyed to us Ibn Abi Zi'bin, from azZuhri, from Abi Salamah bin Abd Rahman, from Abu Hurairah Ra. Said: the Messenger of Allah said: "Every child is born in nature (pure saint), then his parents cause him (child) to become Jewish, to become Christian, or to become a Magi, like a perfectly born cattle, do you see his ear being cut off." (Narrated by Bukhari no.1385).

Ahmad Tafsir explained that according to this hadith, humans were born with abilities. This ability is called innate. While the nature referred to in this hadith is potential. Potential is ability. So, the nature agreed here is innate. The father and mother in this hadith are environments approved by education experts. Both of them are according to this tradition which can determine a person's development. In its development it is a religious difficulty, this is the essence of another form. According to Batubara, (2019) The family has a very big role in teaching, guiding, determining behavior, and forming a perspective on the values that apply in society. The family is like giving the values that are needed by the child through an appropriate communication pattern so that communication goes well, harmonious relationships are created, and the messages and values to be conveyed can be accepted and practiced properly.

According to Quraish Shihab, human nature from the beginning or from birth. In the Qur'an this word is found in various forms repeated 28 times, 14 in the context explanation of the earth and or sky. The rest in human negotiations both in terms of recognition of its creator is God, as well as in terms of description of human nature. The latter is found once in Surah Al-Rum verse 30 of Allah Almighty said, meaning:

"So direct your face toward the religion, inclining to truth. [Adhere to] the fitrah of Allah upon which He has created [all] people. No change should there be in the creation of Allah. That is the correct religion, but most of the people do not know."

Fitrah is a creation, the meaning of the rules that God manifests in every creation. For example humans have physical, intellect and spirit. Abu "Ali Ibn Sina elaborates on the nature of fitrah in the book of al-Najat where he says:" The meaning of fitrah is an explanation of human being created at once, meaning that he is a type that produces understanding. But he has not supported an idea, has not supported a school, has not participated with one people, only he witnessed a concrete object and then he understood the properties of the object, then the reason to respond until he doubted it. If doubt continues to influence it, then nature does not work, and if doubt does not affect, then the decision is determined by nature.

The above verses and traditions become the argument that shows that there is actually something that comes from the instincts and the nature that is intended for aqeedah truly, truly human beings created in a clean and straight environment. Then there are changes and deviations due to environmental influences consisting of lust, deviant knowledge and insight, inheritance of vanity traditions and a very large attitude of taqlid continues for the ancestors, which can be used to think about how and whether there is an aqeedah development effort according with independent, objective and appropriate expectations. If human beings are allowed anything, surely they will not choose other than Islam as a religion because Islam is a religion of nature and reason, a religion that is in accordance with human instincts and nature. According to Nuruddin (2019) an understanding of religion born of scripture must be interpreted. Ironically, a scriptural interpretation is difficult to be released from the ideology and dynamics of the interpreter. Although there will always be a rejection if a scriptural interpretation is ridden by certain interests. 


\section{b. Whispers in the Human Heart}

Angels and Satan become movers or causes of the whispers of the heart. The cause or impulse that urges promptings to virtue is the whisper of angels, and the cause or impulse that urges the whisper of evil is the whisper of Satan. Lathifah or the essence of giving help to the heart in receiving inspiration and this help is called taufiq, and something received from the whisper of Satan is called heresy. Angels are tasked with giving encouragement to do good, reveal the truth and tell the good. The devil is a creature of God with the opposite task of angels, which is to lead to evil and heinous deeds. Thus Allah Most High creating things in pairs. Allah SWT said, meaning:

"And we created everything in pairs so that you will remember the greatness of Allah." (Surat al-Dzariyat: 49)

The human heart lives in the power of attraction between Satan and Angels. Rasulullah Saw. said, meaning:

He has delivered to us Hannad, he said: he has delivered to us Abu al-Ahwash, from Atha 'bin al-Saib, from Murrah al-Hamdani, from Abdullah bin Mas'ud he said: Rasulullah Saw. said: "Indeed Satan has a whisper in humans, angels also have a whisper. The devil's whisper promises badness and denies the truth. While the whispers of angels promise goodness and believe in truth. Whoever gets it, then know that it is from Allah 'Azza wa Jalla, then let him praise Allah' Azza wa Jalla. Whoever gets the other one, he should take refuge in Allah "Azza wa Jalla from the accursed Satan." Then the Prophet read the verse: "Satan promises (frighten) you with poverty and tells you to do evil (miser), (Surah alBaqarah: 268)". (HR. Tirmidhi No. 2988)

Hasan Basri said there were two impulses in the heart, one from Allah and the other from Satan. Allah gives His grace and gifts to those who are compelled to do goodness If the heart is driven to low desires and desires, then you should immediately take refuge in Allah with worship, and if the heart is at the instigation of angels, then stay in this state.

The heart is divided into two, there is a heart that always invites badness and the result is torture and some are inviting goodness and the result is pleasure in the afterlife, both of them are always moving. A good heart will produce inspiration from Allah. While a dirty heart produces anxiety from Satan. During that time the two fought each other.

The influence of the heart from one state to another is called "worry" or the whispers of the heart, and in turn the promptings move the will, ideals and intention. Then the intention can move the limbs. Heart whispers that move intentions are divided into two: goodness and badness. The whisper of the heart to do goodness is called inspiration, and the whisper of the heart to do badness is called anxiety or the whisper of Satan.

\subsection{Fitrah and Its Relationship with Potential of Goodness and Badness in Humans on the Qur'an and Hadith}

Islam is the nature of Allah which He creates soul and reason according to nature, creates it with the instinct to acknowledge its substance and understand, realize, and fully realize its meaning. The Word of Allah Most High, means:

"So direct your face toward the religion, inclining to truth. [Adhere to] the fitrah of Allah upon which He has created [all] people. No change should there be in the creation of Allah. That is the correct religion, but most of the people do not know." (Surah al-Rum: 30)

The above verse states that Islam is a religion of nature, meaning that the religion was designed by Allah in accordance with the nature or the original nature of human events. Thus, human beings are inherent in one potential truth (dinullah). If this potential is used, he will always walk on a straight path, because Allah SWT has guided him since in the spirit realm (in the womb). The Prophet said, meaning:

From Hasan bin Rabi 'told us, from Abu Ahwas told us, from A'masyi from Zaid bin Wahab from Abdullah he said: Rasulullah SAW conveyed to us and he was a righteous and 
justified person: "Verily, every creation is collected in his mother's stomach as a drop of sperm for forty days, then turns into a drop of blood for forty days, then becomes a lump of flesh for forty days. Then sent to him an angel and then blown to his spirit and he was ordered to set four things: determine his fortune, death, charity and accident or happiness. For the sake of Allah, there is no god besides Him, surely among you, there are those who do the deeds of the heavenly expert until the distance between him and heaven remains a cubit, but he has determined the conditions, he does the deeds of the hell, then he enters into hell. Surely some of you have done the deeds of hell experts until the distance between him and hell remains a cubit but it has been determined for him to stipulate, he is doing the deeds of the heavens. (Narrated by Bukhari and Muslim)

In the book of Fath al-Bari, Ibn Hajar al-Asqalani said that, Ibn al-Tin quoted from alDawudi, he said, "This Hadith contains a refutation of people who say that Allah continues to speak with all His words, based on the proposition فَفِيَوَْْرُ بِأَرْبَعِ كَلِمَاتِ الرَّوحُ , as well as Hadith is also a refutation of those who say that if Allah wills it, surely it can punish those who obey. His refutation, it is not the nature of the Most Wise to change His knowledge, because Allah has known since the beginning about who is loved and who is punished. This Hadith covers all human conditions from the beginning of creation, its coming into the world until finally entering heaven or entering hell according to charity while on earth and in accordance with the knowledge, destiny and qada of Allah.

The soul (nafs) was created by Allah. in a perfect state to function to accommodate and encourage people to do good and bad, because it is this side of man that the Qur'an recommends to be given more attention. Although the Qur'an asserts that the nafs has both positive and negative potential, there is also a sign that in essence the positive potential of humans is stronger than the negative potential, only the attraction of evil is stronger than the appeal of goodness. Therefore humans are required to maintain the purity of the soul (nafs) and not pollute it.

That his tendency towards goodness is stronger is understood from the signs of several verses, including His words, meaning:

"Allah does not burden a person but according to his ability. He got the reward (from virtue) that he tried and he got the torture (from evil) that he did, ..... "(Surah al-Baqarah: 286)

The word kasabat in the above verse shows good endeavor so that you get a reward, is a patron used in Arabic to describe work done easily. According to al-Quran expert Muhammad Abduh, it implies that the nafs is actually easier to do good things than to do bad things, and in turn implies that humans were basically created by Allah to do good.

The potential (fitrah) that Allah has given to every human being since he was born into the world needs to be guarded and maintained so as not to fall into the wrong path. To find out how to maintain human nature so that it is always inclined to goodness, it is necessary to know the factors that cause humans to turn away from their fitrah. Thus according to the authors that the way for the potential good is more biased in human beings and also to maintain their nature is as follows.

a. Return to the Religion of Allah

Humans should understand that in their lives in this world there must be clear guidelines, have a strong grip in the form of religion. Religion is a human nature that Allah has. instill in every human being since in the spirit. Humans who have witnessed that Allah is their Lord will be obeyed and obeyed, so that if it is understood by every human being born in this world then there will grow awareness of Allah 's presence and his soul always feels always under His supervision.

b. Purifying the Soul (Tazkiyat al-Nafs) 
Allah SWT. said: "He has succeeded who purifies it, And he has failed who instills it [with corruption]." (QS. al-Shams: 9-10). People who behave mahmudah (praiseworthy) against him is when he is able to cleanse his soul from impurities. The meaning of cleaning dirt here is not the meaning of zahiriyah, what is meant here is that everything that will pollute and pollute the creed and faith possessed by a Muslim. To achieve cleanliness of the heart and purity of the soul there are no specific methods or ways other than to learn and practice the Shari'a religion as a whole.

c. Thinking about the verses of Allah (Qauliyah and Kauniyah)

Many of the verses of the Qur'an invites people to use reason to study and understand the power of Allah. Among them is QS. Ali 'Imran: 7 and 190, QS. Al-Nisa ': 5, QS. alMaidah: 57 and 100, QS. Maryam: 43, QS. al-Rum: 29 and 56, QS. al-Zumar: 9, QS. Muhammad: 16, QS. Saba ': 46, QS. al-Ankabut: 20, QS. al-Haj: 46, QS. al-A'raf: 185.

By seeing a human journey that is so long and is associated with the word of Allah in QS. al-A'raf: 172, then there are several factors that cause humans to turn away from their fitrah. Human's alienation from their nature results in humans being more inclined towards the potential for badness. These factors include:

a. Forget their agreement with Allah

Every human being before birth to this earth has ever been asked to testify to the form of Allah and they watched or knew Him well. Then they brought it up to be born into the world. Therefore, no matter how big they is, strong and rich, they still cannot deny that they does not have their own form and cannot stand alone in managing their affairs.

b. Engage in immoral acts with Allah

Discipline that is continuously carried out by humans can spread and cover the pure heart, then the best solution to cleanse the heart is to avoid disobedience. Allah SWT said in surah al-Shams verses 9-10 which means: "He has succeeded who purifies it, And he has failed who instills it [with corruption]." Based on his word, it turns out there are two human attitudes in treating himself. First are those who treat themselves with the attitude of easy (good character), while the second is madzmumah (bad character).

c. Not Using Intellect properly

In addition to asserting that the problem of monotheism is fitrah, the Qur'an also seeks to encourage people to think with reason that behind the creation of the universe and the changes that occur in it (prove) the existence of a Creator. Verses of the Qur'an that invites to contemplate natural phenomena and the uniqueness of the creatures in them, are very many.

Islam is a religion that is compatible and in line with the instincts and the nature of the upright origin of Allah create humans according to nature and that instinct. Human nature is the event from the beginning or innate since birth. Human nature is also about the creation of human potential, both goodness and badness. There are souls who are instructed and some who are led astray. Everything happens because of Allah. No one can give guidance if Allah wants someone astray, and no one can lead someone astray if Allah wants him to give a way of guidance. So human nature that Allah has set since before there was a human being is very closely related to the potential goodness and badness in humans.

\section{Conclusion}

Wahbah al-Zuhaili argues that there is a balance between the potential of goodness and badness in humans, and all this potential depends on human endeavors, even though from the very beginning humans were born in purity (fitrah). Whereas Quraish Shihab argues that nafs has both positive and negative potentials, there is also a sign that in essence the positive potential of humans is stronger than the negative potential, it's just that the attraction of badness is stronger than the attraction of goodness, therefore humans are required to maintain 
the purity of the soul (nafs) and not littering it. Likewise what is mentioned by Ibn Hajar alAsqalani in Fath al-Bari that humans are pure and holy, that Allah created His creatures as creatures who have the instinct to force Him (monotheism) and the religion of Islam that is pure and holy. So with that goodness will always be more prominent than badness.

So that the potential of goodness is more biased in human beings and also to maintain their nature is to return to the religion of Allah, the kaffah, purifying the soul (Tazkiyat alNafs), thinking about the verses of Allah (Qauliyah and Kauniyah) and keep away from immorality. Thus, the potential of goodness will play a greater role in humans, so the purity of heart must also be guaranteed by applying the things mentioned above.

\section{References}

Abu Dawud Sulaiman bin al-Asy'as bin Ishaq bin Basyir bin Syadad bin 'Amru al-Azdi alSijasitani, Sunan Abi Dawud, Juz 4, Beirut: al-Maktabah al-'Asriyah, t.th.

Abdul Hamid Mursi, SDM yang Produktif: Pendekatan al-Quran dan Sains, Jakarta: Gema Insani Press, 1997.

Ahmad Tafsir, Ilmu Pendidikan dalam Perspektif Islam, Bandung: Remaja Rosdakarya, 1992.

Batubara, M. U., et al. (2019). Islamic Communication Pattern of Judges in Dealing Conflict of Muslim Families in the Religious Court Medan. Budapest International Research and Critics Institute (BIRCI-Journal) : Humanities and Social Sciences, 2(1) 373-386.

Departemen Agama RI, al-Quran dan Terjemahannya, Jakarta: Yayasan Penyelenggara Penterjemah al-Quran, 1971.

Departemen Pendidikan Nasional, Kamus Besar Bahasa Indonesia Pusat Bahasa: Edisi Keempat, Jakarta: Gramedia Pustaka Utama, 2008Didin Hafidhuddin, Membentuk Pribadi Qurani: Di Bawah Bimbingan Syariah, Jakarta: Harakah, 2002.

Enoh, "Konsep Baik (Kebaikan) dan Buruk (Keburukan) dalam al-Quran", dalam Jurnal UNISBA Nomor 23a, 2004.

Fairus, et al. (2018). Face, Posture, and Gesture (Study of Kinesik Aspects in Qur'an). Budapest International Research and Critics Institute (BIRCI-Journal) : Humanities and Social Sciences, 1(4); 330-343.

Harun Nasution, Akal dan Wahyu dalam Islam, Jakarta: UI Press, 1986.

Hendrik, Sehat dengan Shalat, Solo: Tiga Serangkai, 2008.

Ibnu Hajar al-Asqalani, Faht al-Bari Shahih al-Bukhari, Jilid III Dar al-Fikr, t.t.

Khalaf Muhammad al-Husaini, Luruskanlah Akal, Jiwa \& Lisan Anda dengan al-Quran, Terj. Abu Rania dan Kasyful Anwar, Cet. 2, Jakarta: Mustaqim, 2003.

Muhammad bin Ismail Abu Abdullah al-Bukhari Al-Ja'fi, al-Jami' al-Musnad al-Sahih alMukhtasar Min Umuri Rasulillahi Shallallahu 'Alaihi Wasallam wa Ayyamihi: Shahih al-Bukhari, Juz 2, Beirut: Maktabah, t.th.

Muhammad bin Ismail Abu Abdullah al-Bukhari Al-Ja'fi, al-Jami' al-Musnad al-Sahih alMukhtasar Min Umuri Rasulillahi Shallallahu 'Alaihi Wasallam wa Ayyamihi: Shahih al-Bukhari, Juz 4, Beirut: Maktabah, t.th.

Muhammad bin Isa bin Saurah bin Musa bin al-Dhahak al-Tirmidzi, al-Jami' al-Kabir Sunan al-Tirmidzi, Juz 5, Beirut: Dar al-Gharb al-Islami, 1998.

Muslim bin al-Hajjaj Abu al-Hasan al-Qusyairi al-Naisaburi, al-Musnad al-Shahih alMuktashar, Juz 4, Beirut: Dar Ihya' al-Tarats al-'Arabi, t.th.

Muhammad bin Ismail Abu Abdullah al-Bukhari Al-Ja'fi, al-Jami' al-Musnad al-Sahih alMukhtasar Min Umuri Rasulillahi Shallallahu 'Alaihi Wasallam wa Ayyamihi: Shahih al-Bukhari, Juz 1, Beirut: Maktabah, t.th.

Muhammad 'Abd al-Ghafar al-Syarif, Teori Pemberlakuan Syariat Islam Secara Bertahap, Terj. Azman Ismail, dkk, Banda Aceh: ar-Raniry Press, 2003. 
Muhammad bin Isa bin Saurah bin Musa bin al-Dhahak al-Tirmidzi, al-Jami' al-Kabir Sunan al-Tirmidzi, Juz 5, Beirut: Darr al-Gharb al-Islami, 1998.

Mustafa Dieb al-Bugha dan Muyiddin Mistu, al-Wafi Syarah Hadis Arbain Imam Nawawi, Terj. Iman Sulaiman, Jakarta: Pustaka al-Kautsar.

Muhammad Fuad Abdul Baqi, Mu'jam al-Mufahras Li al-Faz al-Quran. Beirut: Dar al-Fikr, 1985.

Nurudddin, A., et al. (2019). Relationship of Interfaith in Tunisia (Critical Study of Ibn 'Ashur Tafsir W.1973). Budapest International Research and Critics Institute (BIRCIJournal) : Humanities and Social Sciences, 2(1) 353-372.

Saryono, "Konsep Fitrah dalam Perspektif Islam", dalam Jurnal Studi Islam Nomor 2, (2016). Umar bin Muhammad bin Salim bin Hafidz, Keajaiban Hati: Membahas Tuntas Mengenai Hati Beserta Sifat, Jenis, serta pembagiannya Menurut al-Quran dan al-Hadis, Terj. Yunus bin Ali al-Muhdhor, Surabaya: Cahaya Ilmu, 2012.

Wahbah al-Zuhaili, Tafsir al-Munir: Aqidah, Syariah dan Manhaj, Terj. Abdul Hayyie alKattani, dkk, Jilid 11, Cet. 1, Jakarta: Gema Insani, 2016. 